changed and sensitivity to chloramphenicol is constant. There has been no change in the product used, the dose, or length of treatment. The reason why the response to chloramphenicol has become less satisfactory remains obscure.

Reports of treatment of typhoid carriers with amoxycillin cover few cases. ${ }^{11}{ }^{12}$ So far nine of the 11 children who became carriers after chloramphenicol treatment have been given a single 21-day course of amoxycillin with success. This contrasts favourably with past experience, when ampicillin, in high doses over long periods, sometimes failed. In view of the success in treating these few carriers it seems worth while to evaluate amoxycillin in the management of the asymptomatic carrier state in different areas where typhoid fever is endemic.

Amoxycillin is undoubtedly safe and readily acceptable, and on the evidence of its success in symptomatic typhoid fever may well become the drug of first choice in this disease.

I am indebted to Professor P C Appelbaum, Dr A F Hallett, and Mrs A Bowen of the department of microbiology for their help; my colleagues in the departments of paediatrics, chemical pathology, and haematology for their help; Dr A Wesley for the statistical analysis; and the medical superintendent, Dr H R J Wannenburg, for facilities.

\section{References}

${ }^{1}$ Scragg, J N, Rubidge, C J, and Wallace, H L, Archives of Disease in Childhood, 1969, 44, 18

2 Scragg, J N, and Rubidge, C J, British Medical fournal, 1971, 3, 738.

3 Colquhoun, J, and Weetch, R C, Lancet, 1950, 2, 621.

4 Anderson, E S, and Smith, H R, British Medical fournal, 1972, 3, 329.

${ }^{5}$ Gonzalez-Cortes, A, et al, British Medical fournal, 1973, 2, 605.

${ }^{6}$ Butler, T, et al, British Medical fournal, 1973, 2, 983.

' Overturf, G, Marton, K I, and Mathies, A E, New England fournal of Medicine, 1973, 289, 463.

8 Calderon, E, fournal of Infectious Diseases, 1974, 129, 219.

- Scragg, J N, and Rubidge, C J, American fournal of Tropical Medicine and Hygiene, 1975, 24, 860 .

${ }^{10}$ Pillay, N, Adams, E B, and North-Coombes, D, Lancet, 1975, 2, 333.

${ }^{11}$ Kosmidis, J, et al, British fournal of Clinical Practice, 1972, 26, 341.

12 Munnich, D, et al, Chemotherapy, 1974, 20, 29.

\title{
Amoxycillin in treatment of typhoid fever in patients with haematological contraindications to chloramphenicol
}

\author{
A M AFIFI, M ADNAN, A A EL GARF
}

British Medical fournal, 1976, 2, 1033-1034

\section{Summary}

Thirty adults with proved typhoid fever were treated with amoxycillin $1 \mathrm{~g}$ six-hourly by mouth for an average of 14 days because of haematological contraindications to chloramphenicol. Eighteen patients were Egyptian men with the Mediterranean variety of glucose-6-phosphate dehydrogenase deficiency and an enzyme activity in the red cells ranging from 0 to $3 \%$, and 12 patients had a history of severe but reversible myelosuppression after eight to 12 days' treatment with chloramphenicol 1.5-2 g daily. The clinical and bacteriological responses in this group of patients were compared with those of 30 haematologically normal patients of comparable age and sex treated with chloramphenicol.

The results showed that amoxycillin is an effective alternative to chloramphenicol for treating typhoid fever in patients with haematological contraindications to chloramphenicol.

\section{Introduction}

Although typhoid fever is not endemic in Egypt, it is a common cause of pyrexia of undetermined origin in adult Egyptians. This fact is overemphasised by general practitioners, who usually start treating patients with pyrexia of undetermined origin with chloramphenicol before the laboratory tests for the diagnosis of enterica have proved or disproved the presumptive diagnosis of typhoid fever. This, together with the prevailing practice by

Maadi Armed Forces Hospital, Cairo, Egypt

A M AFIFI, MRCP, FRCP, consultant haematologist

M ADNAN, MB, DM, assistant haematologist

A A EL GARF, MB, registrar, haematology department many ear, nose, and throat specialists of using chloramphenicol as the drug of choice for upper respiratory tract and ear infections, has resulted in excessive use of chloramphenicol in medical practice in Egypt.

Among the many patients subjected to one or several courses of chloramphenicol some have shown definite but transient haematological toxicity characterised by a delayed clinical onset of moderate depression of bone marrow cellularity and a single reversible cytopenia or pancytopenia. This type of toxicity, described by Best $^{1}$ as intermediate between the irreversible aplasia of delayed onset and the dose-dependent transient erythroid depression, is the commonest form of chloramphenicolinduced blood dyscrasia observed by Egyptian haematologists. It is considered to be an idiosyncratic reaction to chloramphenicol of transient type which leads to a short-lived episode of bone marrow aplasia of either one or more of the three elements of haematopoiesis. In addition to the gradually increasing number of patients belonging to this category, a fixed percentage of Egyptian men suffer from the Mediterranean variety of glucose-6phosphate dehydrogenase deficiency. ${ }^{2}$ These patients may develop haemolysis and jaundice with fever, and their haemolysis may be aggravated by the administration of challenging agents such as chloramphenicol to the enzyme deficient red cells.

These two facts prompted us to carry out a clinical trial of an alternative drug that could replace chloramphenicol in the treatment of typhoid fever in these patients. Amoxycillin (D(-) $\alpha$-amino-p-hydroxybenzylpenicillin trihydrate) $1 \mathrm{~g}$ sixhourly was chosen for the trial in view of its safety and its considerably higher serum concentrations than ampicillin. ${ }^{3}$ Reports have shown the success of amoxycillin in treating typhoid fever in several groups of patients. ${ }^{4-6}$ We believed that running a clinical trial of amoxycillin in the treatment of typhoid fever in these two groups of patients was justifiable.

\section{Patients and methods}

Thirty adults suffering from typhoid fever and ranging in age from 16 to 38 years were included in the trial. Eighteen were men suffering from severe Mediterranean glucose-6-phosphate dehydro- 
genase deficiency. The enzyme assay for these patients, carried out by the method of Glock and McLean, ${ }^{7}$ showed either no enzyme activity or an activity below 0.01 units, which is less than $3 \%$ of the normal activity. The remaining 12 patients had developed a transient episode of bone marrow hypoplasia three to eight weeks after a course of chloramphenicol. The daily dose of chloramphenicol was 1.5 to $2 \mathrm{~g}$; and the course lasted from 8 to 12 days. The 12 patients, who all showed marrow hypoplasia and vacuolation of the normoblasts, developed moderate anaemia with a haemoglobin level of 8.6-10 g/ $\mathrm{dl}$ and leucopenia with a neutrophil count below $1.5 \times 10^{9} / 1(1500 /$ $\mathrm{mm}^{3}$ ). Five also developed thrombocytopenia with a platelet count below $100 \times 10^{9} / 1\left(100000 / \mathrm{mm}^{3}\right)$. The 12 patients recovered from the hypoplastic episode after eight to 14 weeks' treatment in the haematology unit.

Before the start of specific treatment blood, urine, and stool samples were taken. The diagnosis of typhoid fever was confirmed in all the patients by a positive blood culture for Salmonella typhi and treatment with amoxycillin was delayed until the blood culture results were known.

Complete blood picture; urine and stool examination including examination for $S$ typhi; Widal test, liver function tests including measurement of serum bilirubin, serum aspartate transaminase, and alkaline phosphatase ; and serum electrolyte and blood urea estimations were carried out for all the patients. Patients with glucose-6-phosphate dehydrogenase deficiency underwent daily estimation of their haemoglobin concentration and serum bilirubin level during the period of fever. Blood culture for $S t y p h i$ was repeated every five days from the date of the diagnosis up to 15 days after the temperature dropped to normal. Amoxycillin was given by mouth in a dose of $1 \mathrm{~g}$ six-hourly for 12-16 days (mean 14 days), after which the blood picture was repeated and serum bilirubin measured weekly for two weeks. The same laboratory tests were carried out in 30 haematologically normal patients aged 17 to 40 years who were treated with chloramphenicol $1 \mathrm{~g}$ eight-hourly until defervescence followed by $500 \mathrm{mg}$ six-hourly for one week thereafter.

\section{Results}

Clinical response was judged by relief of toxicity, improvement in wellbeing, return of appetite, and finally drop of temperature to $37.5^{\circ} \mathrm{C}$ or less. Twenty-four patients showed striking clinical improvement after three to five days, five improved after six to eight days, and one improved after 12 days. Settlement of temperature to $37.5^{\circ} \mathrm{C}$ or less lagged two to three days after the onset of the clinical improvement. The haemoglobin level in the 12 patients suffering from glucose6-phosphate dehydrogenase deficiency did not drop by more than $1.8 \mathrm{~g} / \mathrm{dl}$ during the period of fever and the serum bilirubin concentration did not rise by more than $18.8 \mu \mathrm{mol} / 1(1.1 \mathrm{mg} / 100 \mathrm{ml})$ from the pretreatment values (table I). This indicated mild or moderate haemolytic processes. Table II shows the clinical and bacteriological response pattern in the patients treated with amoxycillin compared with that of the 30 normal patients treated with oral chloramphenicol.

TABLE I-Haemoglobin and serum bilirubin estimations before and during fever and convalescence in the glucose-6-phosphate dehydrogenase deficient patients

\begin{tabular}{|c|c|c|c|c|}
\hline \multirow{2}{*}{ Case } & \multicolumn{2}{|c|}{ Haemoglobin ( $\mathrm{g} / \mathrm{dl})$} & \multicolumn{2}{|c|}{ Bilirubin $(\mu \mathrm{mol} / \mathrm{l})$} \\
\hline & $\begin{array}{l}\text { Before } \\
\text { disease }\end{array}$ & $\begin{array}{l}\text { During } \\
\text { disease }\end{array}$ & $\begin{array}{l}\text { Before } \\
\text { disease }\end{array}$ & $\begin{array}{l}\text { During } \\
\text { disease }\end{array}$ \\
\hline $\begin{array}{r}1 \\
2 \\
3 \\
4 \\
5 \\
6 \\
7 \\
8 \\
9 \\
10 \\
11 \\
12\end{array}$ & $\begin{array}{r}10 \\
11.3 \\
1.4 \\
9.6 \\
11.6 \\
10.4 \\
10.7 \\
11.0 \\
9.6 \\
11.6 \\
10.7 \\
10.0\end{array}$ & $\begin{array}{c}8 \cdot 2-9 \cdot 6 \\
10 \cdot 4-11 \cdot 0 \\
8 \cdot 8-10 \cdot 0 \\
8 \cdot 4-9 \cdot 2 \\
10 \cdot 4-11 \cdot 0 \\
9 \cdot 6-10 \\
9 \cdot 2-10 \\
10 \cdot 4-10 \cdot 7 \\
8 \cdot 4-9 \cdot 2 \\
10 \cdot 7 \cdot 11 \cdot 0 \\
9 \cdot 6-10 \cdot 4 \\
8 \cdot 4-9 \cdot 6\end{array}$ & $\begin{array}{l}20 \cdot 5 \\
13 \cdot 7 \\
22 \cdot 2 \\
34 \cdot 2 \\
15 \cdot 4 \\
18 \cdot 8 \\
20 \cdot 5 \\
15 \cdot 4 \\
35 \cdot 9 \\
13 \cdot 7 \\
23 \cdot 9 \\
34 \cdot 2\end{array}$ & $\begin{array}{l}25 \cdot 7-34 \cdot 2 \\
20 \cdot 5-25 \cdot 7 \\
30 \cdot 8-34 \cdot 2 \\
42 \cdot 8-47 \cdot 9 \\
20 \cdot 5-34 \cdot 2 \\
27 \cdot 4-35 \cdot 9 \\
30 \cdot 8-35 \cdot 9 \\
25 \cdot 7-34 \cdot 2 \\
42 \cdot 8-54 \cdot 7 \\
20 \cdot 5-34 \cdot 2 \\
27 \cdot 4-42 \cdot 8 \\
42 \cdot 8-53 \cdot 0\end{array}$ \\
\hline
\end{tabular}

Conversion: SI to traditional units-Bilirubin: $1 \mu \mathrm{mol} / 1 \approx 0.06 \mathrm{mg} / 100 \mathrm{ml}$.

The incidence of relapse, defined as a recurrence of symptoms after initial response and reisolation of $S$ typhi on blood culture, was also compared in both groups, together with the incidence of the other common complications (see table II).
TABLE II-Clinical and bacteriological responses and complications in the two groups of patients

\begin{tabular}{l|c|c}
\hline & $\begin{array}{c}\text { Group with G-6-P-D } \\
\text { deficiency treated } \\
\text { with amoxycillin }\end{array}$ & $\begin{array}{c}\text { Normal group } \\
\text { treated with } \\
\text { chloramphenicol }\end{array}$ \\
\hline $\begin{array}{l}\text { Time required for satisfactory } \\
\text { clinical response (days) }\end{array}$ & $6 \cdot 2(3-12)$ & $8 \cdot 8(3-14)$ \\
$\begin{array}{l}\text { Time taken for return to normal } \\
\text { temperature (days) }\end{array}$ & $\begin{array}{l}7 \cdot 5(5-13) \\
\text { Alood culture on 15th day }\end{array}$ & $\begin{array}{l}10(5-16) \\
2 \text { positive, } \\
28 \text { negative }\end{array}$ \\
$\begin{array}{l}\text { No with peritonitis and internal } \\
\text { haemorrhage }\end{array}$ & $\begin{array}{l}\text { None } \\
\text { No of deaths }\end{array}$ & 2 \\
\hline
\end{tabular}

\section{Discussion}

The two groups of patients included in the trial suffered from different haematological abnormalities, but they both shared the common problem of developing predictable and serious haematological complications on administration of chloramphenicol. The gravity of the complications makes the doctor hesitate before deciding on giving chloramphenicol to these patients even when chloramphenicol is the most effective specific antimicrobial agent, as was the case with typhoid fever a few years ago.

In severe Mediterranean glucose-6-phosphate dehydrogenase deficiency the red cells undergo haemolysis either spontaneously or with mild infection because of their low or absent enzyme activity. It is important to emphasise that the synergic action between glucose-6-phosphate dehydrogenase deficiency and infection in the pathogenesis of haemolysis may turn benign haemolysis produced by a drug such as chloramphenicol into a severe haemolysis. The haemolytic episode might even be life threatening and require blood transfusion, since men with homozygous inheritance of Mediterranean glucose-6-phosphate dehydrogenase deficiency have only a single population of grossly enzyme-deficient red cells that undergo extensive haemolysis on exposure to two challenging agents.

The drop in haemoglobin concentration in the glucose-6phosphate dehydrogenase deficient patients during the toxaemic period of the disease did not result in life-threatening anaemia demanding blood transfusion, as the maximum drop did not exceed $1.8 \mathrm{~g} / \mathrm{dl}$. This was partly due to the efficacy of amoxycillin in rapidly controlling the activity of the disease, even faster than chloramphenicol, thus reducing the time during which the vulnerable red cells were exposed to the lethal toxaemia, and partly due to the absolute safety of the drug both to the regenerative erythroid activity of the bone marrow and to the newly formed red cell population.

In the second group of patients, who showed idiosyncratic myelosuppression and normoblastic vacuolation on previous intake of chloramphenicol, the degree of risk of exposing the marrow to the hazard of chloramphenicol is unpredictable and might exceed in its gravity the previous episode, possibly even causing irreversible aplasia. It is therefore wise to consider that the administration of chloramphenicol is absolutely contraindicated in these patients.

In view of the greater effectiveness of amoxycillin compared with chloramphenicol, amoxycillin should be considered as the drug of choice for treating typhoid fever in patients with haematological contraindications to chloramphenicol.

\section{References}

${ }^{1}$ Best, W, Fournal of the American Medical Association, 1967, 201, 181.

2 Kamal, I, et al, Acta Genetica et Statistica Medica, 1967, 17, 321.

3 Tan, J S, Bannister, T, and Phair, J P, fournal of Infectious Diseases, 1974, 129, June suppl, p 129.

4 Calderon, E, fournal of Infectious Diseases, 19.74, 129, June suppl, p 219.

5 Farid, Z, et al, Lancet, 1974, 1, 350.

- Pillay, N, Adams, E B, and North-Coombes, D, Lancet, 1975, $2,353$.

7 Glock, G E, and McLean, P, Biochemical fournal, 1953, 55, 400. 